DOI https://doi.org/10.18551/rjoas.2018-08.51

\title{
BEEF MARKET INTEGRATION IN EAST NUSA TENGGARA OF INDONESIA
}

\author{
Nendissa Doppy Roy* \\ Department of Agribusiness, Faculty of Agriculture, University of Nusa Cendana, Kupang \& \\ Doctoral Program of Agriculture Sciences, University of Brawijaya, Malang, Indonesia
}

\author{
Anindita Ratya, Hanani Nuhfil, Muhaimin Abdul Wahib \\ Faculty of Agriculture, Brawijaya University, Malang, Indonesia \\ *E-mail: bramroy213@gmail.com
}

\begin{abstract}
East Nusa Tenggara Province is a cattle producer that is sent to Jakarta. When fluctuations in beef prices are relatively large, there is a tendency that price trend at the producer level in East Nusa Tenggara Province does not follow the price at the consumer level in Jakarta. This study uses monthly price data for 2014-2017 at the producer and consumer level in East Nusa Tenggara and prices in Jakarta. The results of the study showed that a large change in the market price of beef in Jakarta is followed by a small change in consumer prices in the city of Kupang. While the price of beef producers in Kupang district is not determined by the price of meat in Jakarta but follows changes in the price of meat in the Kupang city. This means that changes in beef prices in Jakarta are always followed by changes in the price of beef in Kupang but with relatively small price changes so that the chance of cattle in Kupang District to be sent to Jakarta is getting bigger.
\end{abstract}

\section{KEY WORDS}

Prices, producer, consumer, Jakarta.

The demand for beef in Indonesia every year continues to increase along with the increase in income and population growth but not followed by an increase in production. The prognosis of beef demand throughout 2017 reached 604,966 tons while the domestic meat production target was only 354,770 tons or $58.64 \%$, meaning that there was a deficiency of $41.36 \%$ of the need (Ministry of Agriculture RI, 2017). This results in the need for beef to be imported every year.

The need for beef in Indonesia is one of which comes from the Province of East Nusa Tenggara. East Nusa Tenggara Province, as one of the 4th largest province in Indonesia beef cattle province, sends out NTT as many as 50,000 to 70,000 where every year, wherein 2017 it reached 60,360 or around $2.43 \%$ of domestic beef needs and as much as 49,790 tails $(82.49 \%)$ came from the mainland of Timor, especially Kupang District; (Pusdatin Ministry of Agriculture RI, 2017 and NTT Agriculture Office, 2017).

According to NTT's Livestock Service data (2017), NTT province has the opportunity to increase cattle production if there are price incentives that encourage farmers to increase production. The incentive for beef prices depends a lot on price increases that often occur in the increase in beef prices in Indonesia due to lack of supply.

Beef price movements in Indonesia tend to depend on increased demand for beef, especially on religious events. Increased beef price movements in the consumer market should be followed by price increases in the producer market. If there is a price increase at the producer level, it is expected to be a price incentive for producers to increase production. But often the price increase in consumers is not directly transmitted or not integrated into the producer market. The pattern of livestock business is still extensively traditional and the lack of access to market information is an internal obstacle. Whereas, the condition of transportation infrastructure and the distance between distant markets, as well as government policies limiting the quota of sending cattle out of NTT, are external barriers. According to Goletti; et al, (1994) in Anindita \& Baladina (2017), several factors that influence market integration are marketing infrastructure (transportation and storage facilities); public 
intervention; production imbalances between regions and the presence of shock supply (natural disasters or extraordinary events). These four factors are still an obstacle to the integration of cattle markets in Kupang and NTT generally.

The concept of marketing efficiency is closely related to the concept of market integration (Sharp \& Uebele, 2013). The an operational definition of market integration is known as the Law of One Price, meaning that the same product is sold at relatively the same price in various markets and is only distinguished by transportation costs (Monke \& Petzel 1984; Crucini, et al, 2010) or other services. Based on this understanding, identification of market integration can be done by analyzing the inter-market price relationship.

A the market is said to be integrated if there is a price change in one market so it will be forwarded to other markets quickly, it can be caused because the market information system is running well. According to Asmarantaka (2009), market integration is a measure that shows the extent to which price changes that occur in the reference market will cause changes in the market of followers. While market integration occurs according to Baffes \& Gardner; (2003) if there is equal market information, it is sufficient, directly channeled quickly to other markets and has a positive relationship between prices in different markets. So that an integrated market will provide justice to all market participants in carrying out their activities.

\section{METHODS OF RESEARCH}

Data Stationary Test. According to Makridakis et al. (1999), a series of observations are said to be stationary if the process does not change with time. This stationary data test uses Augmented Dickey-Fuller (ADF) at the same level (level or different) until stationary data is obtained, ie the variance is not too large and has a tendency to approach its mean value (Enders, 1995).

Widarjono (2013) explained that the ADF test function is to see whether there is a trend in the movement of data to be tested. The ADF test in this study is as follows:

$$
\Delta \mathrm{P}_{\mathrm{t}}=\mathrm{a}_{0}+\mathrm{Y}_{1} \mathrm{P}_{\mathrm{t}-1}+\beta_{\mathrm{I}} \sum_{\mathrm{I}=1}^{\mathrm{m}} \Delta \mathrm{P}_{\mathrm{t}-1}+\varepsilon_{\mathrm{it}}
$$

Where:

$P_{t}=$ The price of beef in each market in period $t$;

$\mathrm{P}_{\mathrm{t}-1}=$ Price of beef in each market in the previous period;

$\Delta \mathrm{P}_{\mathrm{t}}=\mathrm{P}_{\mathrm{t}}-\mathrm{P}_{\mathrm{t}-1}$

$\Delta \mathrm{P}_{\mathrm{t}-1}=\mathrm{P}_{\mathrm{t}-1}-\Delta \mathrm{P}_{(\mathrm{t}-1)-1}$

$\mathrm{m}=$ amount of lag;

$\alpha_{0}=$ intercept;

$\alpha, \beta, \gamma=$ Parameter coefficient;

$\varepsilon_{\mathrm{t}}=$ Error term.

Hypothesis testing:

$\mathrm{H}_{0}: \mathrm{Y}=0$ Time series data is not stationary;

$\mathrm{H}_{1}: \mathrm{Y}<0$ time series data is stationary.

Test rules:

- If ADF statistics > ADF is critical then rejecting Ho means that the time series data does not contain the unit root means that the data is not stationary;

- If ADF statistics $\leq A D F$ is critical then accept Ho means the time series data contains the unit root means that the data is stationary.

Determination of Optimal Lag. Optimal lag length is needed to see the effect of each variable on other variables in the VAR model. The value of the lag of a variable can affect other variables because it takes time for a variable to respond to the movement of other variables. Determination of optimal lag length using Akaike Information Criteria (AIC). 
Cointegration Test. Cointegration Test is carried out if the price variables studied are not integrated at the level. This test uses Johansen's Cointegration Test, to find out whether there is integration or not.

Granger's Causality Test. Granger's causality test is used to see short-term causality of each variable that has root and cointegrate (Sulistiana; 2017).

Vector Error Correction Model (VECM) Test. The VECM model is used to overcome the data stationary, where this model will gradually correct the imbalance, deviating through short-term partial adjustments (Enders, 1995; and Gujarati, 2004). The VAR / VECM model in this study is as follows:

$$
\begin{aligned}
& \Delta \mathrm{PKab}_{\mathrm{t}}=\mathrm{a}_{0}+\sum_{\mathrm{I}=1}^{\mathrm{p}} \mathrm{a}_{\mathrm{i}} \Delta \mathrm{PKab}_{\mathrm{t}-1}+\sum_{\mathrm{I}=1}^{\mathrm{p}} \beta_{\mathrm{i}} \Delta \mathrm{PKot}_{\mathrm{t}-1}+\sum_{\mathrm{I}=1}^{\mathrm{p}} \mathrm{Y}_{\mathrm{i}} \Delta \mathrm{PJkt}_{\mathrm{t}-1}+\varepsilon_{1 \mathrm{t}} \\
& \Delta \mathrm{PKot}_{\mathrm{t}}=\delta_{0}+\sum_{\mathrm{l}=1}^{\mathrm{p}} \delta_{\mathrm{i}} \Delta \mathrm{PKab}_{\mathrm{t}-1}+\sum_{\mathrm{I}=1}^{\mathrm{p}} \sigma_{\mathrm{i}} \Delta \mathrm{PKot}_{\mathrm{t}-1}+\sum_{\mathrm{l}=1}^{\mathrm{p}} \phi_{\mathrm{i}} \Delta \mathrm{PJkt}_{\mathrm{t}-1}+\varepsilon_{1 \mathrm{t}} \\
& \Delta \mathrm{PJkt}_{\mathrm{t}}=\theta_{0}+\sum_{\mathrm{l}=1}^{\mathrm{p}} \theta_{\mathrm{i}} \Delta \mathrm{PKab}_{\mathrm{t}-1}+\sum_{\mathrm{I}=1}^{\mathrm{p}} \omega_{\mathrm{i}} \Delta \mathrm{PKot}_{\mathrm{t}-1}+\sum_{\mathrm{I}=1}^{\mathrm{p}} \varphi_{\mathrm{i}} \Delta \mathrm{PJkt}_{\mathrm{t}-1}+\varepsilon_{1 \mathrm{t}}
\end{aligned}
$$

Where: $\Delta \mathrm{PKab}_{\mathrm{t}}=$ The price of beef in the producer market of Kupang district in the period $\mathrm{t}$ $(\mathrm{Rp} / \mathrm{Kg}) ; \Delta \mathrm{PKab}_{\mathrm{t}-1}=$ The price of beef in the producer market of Kupang district in the previous period $\mathrm{t}(\mathrm{Rp} / \mathrm{kg}) ; \Delta \mathrm{PKot}_{\mathrm{t}}=$ The price of beef in the Kupang city market in the periode to $\mathrm{t}(\mathrm{Rp} / \mathrm{kg}) ; \Delta \mathrm{PKot}_{\mathrm{t}-1}=$ The price of beef in the Kupang city market in the previous to $\mathrm{t}$ $(\mathrm{Rp} / \mathrm{kg}) ; \Delta \mathrm{PJkt}_{\mathrm{t}}=$ The price of beef in the Jakarta market in the period to $\mathrm{t}(\mathrm{Rp} / \mathrm{kg})$; $\Delta \mathrm{PJkt}_{\mathrm{t}-1}=$ The price of beef in the Jakarta market in the previous to $\mathrm{t}(\mathrm{Rp} / \mathrm{kg}) ; \mathrm{A}, \delta, \theta, \beta, \mathrm{Y}, \sigma$, $\varphi, \omega, \phi=$ regression coefficient; $\varepsilon_{i \mathrm{t}}=$ error term to $-\mathrm{i}$, time to $-\mathrm{t}$.

\section{RESULTS AND DISCUSSION}

Analysis of fluctuations in beef prices. Based on the analysis of monthly beef price movements in 2012-2017 in Kupang district as a producer area, Kupang city as a consumer area and jakarta as a consumer center in Indonesia showed that the price trend of beef in the three market has increased. However, variations and patterns of price increases are not the same because price increases in Jakarta are immediately followed by price increases in Kupang city and Kupang districts, (Figure 1).

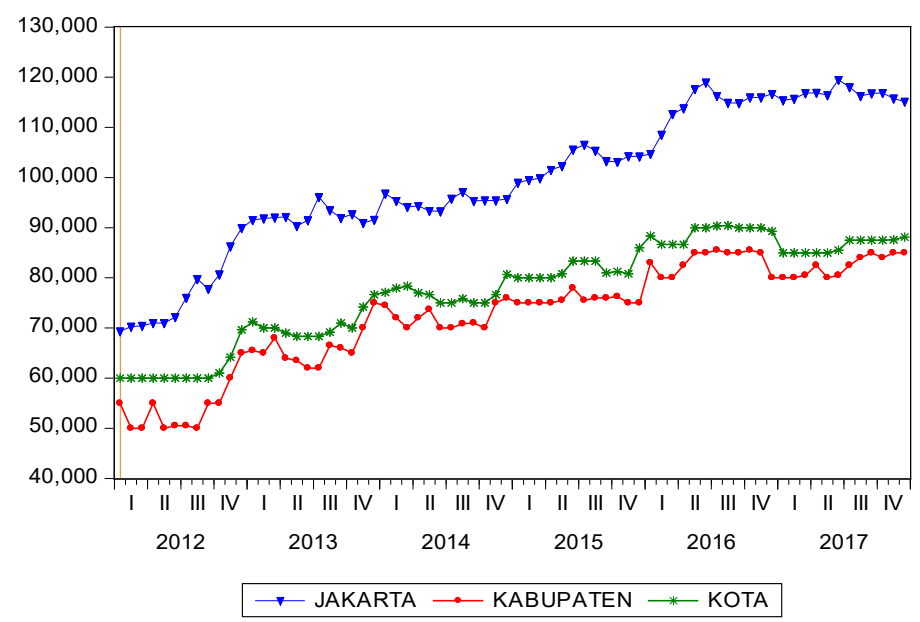

Figure 1 - Fluctuations in Monthly Prices of Beef in Kupang District, Kupang City and Jakarta, 2012-2017

The price swing pattern is not the same in all three markets, indicating that changes in price increases in Jakarta are not directly followed by prices in the Kupang city and also price increases in Kupang District and vice versa. This condition is allegedly due to the slow flow of information (asymmetric information) from the market in Jakarta to the Kupang city and the market in Kupang district, as well as infrastructure and commodity cycle constraints in the form of selling time and business patterns. According to Fakari, et al, (2013) in the study of 
fluctuations and cycles of prices of agricultural commodities (corn) in Iran, finding that each commodity often has its own price movement cycle.

Analysis of Market Integration of Beef. The results of stationary data test time series prices at the level of the level indicate that the data on meat prices are not stationary. Then continued the ADF test at the first difference level. At this level the data has been stationary, shown in table 1, with the ADF statistic value <ADFcritical, with a confidence level $(\alpha)=0.10$.

Table 1 - Results of Stationary Data Test at Level Levels and, Levels of First Difference with ADF Test

\begin{tabular}{|c|c|c|c|c|c|c|c|}
\hline \multirow{2}{*}{ Variable } & \multirow{2}{*}{ Differenced } & \multirow{2}{*}{ ADF Statistic } & \multicolumn{3}{|c|}{ Critical Value } & \multirow{2}{*}{ p-value } & \multirow{2}{*}{ Description } \\
\hline & & & $1 \%$ & $5 \%$ & $10 \%$ & & \\
\hline \multirow[t]{2}{*}{ P_KABU } & $\mathrm{I}(0)$ & -1.3090 & -3.5256 & -2.9030 & -2.5889 & 0.6212 & NS \\
\hline & $\mathrm{I}(1)$ & -7.5480 & -3.5285 & -2.9042 & -2.5896 & $0.0000^{* *}$ & $S$ \\
\hline \multirow[t]{2}{*}{ P_KOTA } & $\mathrm{I}(0)$ & -1.4659 & -3.5357 & -2.8330 & -2.4897 & 0.5451 & NS \\
\hline & $\mathrm{I}(1)$ & -6.5222 & -3.5270 & -2.9036 & -2.5892 & $0.0000^{* *}$ & $\mathrm{~S}$ \\
\hline \multirow[t]{2}{*}{ P_JAKARTA } & $\mathrm{I}(0)$ & -2.0996 & -3.5446 & -2.9124 & -2.6564 & 0.2455 & NS \\
\hline & $\mathrm{I}(1)$ & -4.2451 & -3.5316 & -2.9055 & -2.5903 & $0.0012^{* *}$ & $S$ \\
\hline
\end{tabular}

Source: Secondary Data Processed, $2018^{* *}=(\alpha) 0.05$; and * $=(\alpha) 0.10$.

Description: I (0) = at Level I(1) = at first Difference.

$T S=$ None Stationary $S=$ Stationary .

Determination of Optimal Lag. The next step determines the optimal lag length, obtained the results are at lag 4 at the smallest AIC value of 53.24123*, shown in Table 2 . This means that in the optimal lag all the variables in the model influence each other, not only in the period currently but also the price variables are interrelated in the previous 4 periods. Determination of optimal lag to eliminate autocorrelation and heteroscedasticity.

Table 2 - Optimal Lag Determination Test Results

\begin{tabular}{lllllll}
\hline Lag & LogL & LR & FPE & AIC & SC & HQ \\
\hline 0 & -1741.7950 & NA & $4.15 e+19$ & 53.68601 & $53.78637^{*}$ & $53.72561^{*}$ \\
1 & -1731.3850 & 19.53856 & $3.98 \mathrm{e}+19$ & 53.64263 & 54.04405 & 53.80102 \\
2 & -1721.0190 & 18.49988 & $3.82 \mathrm{e}+19$ & 53.60059 & 54.30308 & 53.87777 \\
3 & -1709.4960 & 19.50036 & $3.55 \mathrm{e}+19$ & 53.52296 & 54.52652 & 53.91893 \\
4 & -1691.3400 & $29.04972^{*}$ & $2.70 \mathrm{e}+19^{*}$ & $53.24123^{*}$ & 54.54587 & 53.75599 \\
5 & -1688.8530 & 3.749518 & $3.35 \mathrm{e}+19$ & 53.44163 & 55.04734 & 54.07519 \\
6 & -1680.8550 & 11.32036 & $3.53 \mathrm{e}+19$ & 53.47246 & 55.37923 & 54.22481 \\
\hline
\end{tabular}

Source: Secondary Data Processed, 2018.

The results of cointegration of beef prices in Kupang district and in the Kupang city and prices in the Jakarta city are presented in Tables 3, 4 and 5.

Table 3 - Cointegration Test between Markets in Kupang District and Kupang City Market

\begin{tabular}{lllllll}
\hline $\begin{array}{l}\text { Hypothesized No. of } \\
\text { CE }(\mathrm{s})\end{array}$ & $\begin{array}{l}\text { Trace } \\
\text { Statistic }\end{array}$ & $\begin{array}{l}0.05 \text { Critical } \\
\text { Value }\end{array}$ & \multirow{2}{*}{ Prob. ${ }^{* *}$} & Max-Eigen Statistic & $\begin{array}{l}0.05 \text { Critical } \\
\text { Value }\end{array}$ & Prob. $^{* *}$ \\
\hline None ${ }^{*}$ & 15.7351 & 15.4947 & $0.0460^{* *}$ & 12.4338 & 14.2646 & 0.0954 \\
At most 1 & 3.3013 & 3.8415 & 0.0692 & 3.3013 & 3.8415 & 0.0692 \\
\hline
\end{tabular}

Source: Secondary Data Processed, $2018^{* *}=(\alpha) 0,05^{*}=(\alpha) 0,10$.

Table 4 - Cointegration Tests between Markets in Kupang City and Jakarta Market

\begin{tabular}{|c|c|c|c|c|c|c|}
\hline $\begin{array}{l}\text { Hypothesized No. of } \\
\mathrm{CE}(\mathrm{s})\end{array}$ & $\begin{array}{l}\text { Trace } \\
\text { Statistic }\end{array}$ & $\begin{array}{l}0.05 \text { Critical } \\
\text { Value }\end{array}$ & Prob.** & Max-Eigen Statistic & $\begin{array}{l}0.05 \text { Critical } \\
\text { Value }\end{array}$ & Prob.** \\
\hline None * & 11.36262 & 15.49471 & 0.1902 & 7.028929 & 14.26460 & 0.4857 \\
\hline At most 1 & 4.333691 & 3.841466 & 0.0374 & 4.333691 & 3.841466 & 0.0374 \\
\hline
\end{tabular}

Source: Secondary Data Processed, $2018^{* *}=(\alpha) 0,05^{*}=(\alpha) 0,10$.

Table 3 shows that producer prices in kupang district are cointegrated in the long-term with the prices of consumers in kupang district with Trace Statistics $>$ Critical values with Prob 
$<0.10$ means that there is an integration of beef prices in the long run between the Kupang city market and the Kupang district market.

Table 4 shows the price of beef in Kupang city and in Jakarta. The data shows the Trace Statistics < Critical value, with Prob> 0.10, meaning that there is no integration. This means that changes in beef prices that occur in Jakarta are not followed by changes in the price of beef in the Kupang city.

The same thing occurred between the prices of beef in Kupang district does not follow the price of beef in Jakarta, as presented in table 5.

Table 5 - Cointegration Tests between Markets in Kupang District and Jakarta Market

\begin{tabular}{|c|c|c|c|c|c|c|}
\hline $\begin{array}{l}\text { Hypothesized } \\
\text { No. of CE(s) }\end{array}$ & $\begin{array}{l}\text { Trace } \\
\text { Statistic }\end{array}$ & $\begin{array}{l}0.05 \text { Critical } \\
\text { Value }\end{array}$ & Prob.** & $\begin{array}{l}\text { Max-Eigen } \\
\text { Statistic }\end{array}$ & $\begin{array}{l}0.05 \text { Critical } \\
\text { Value }\end{array}$ & Prob.** \\
\hline None * & 12.4636 & 15.4947 & 0.1360 & 7.4363 & 14.2646 & 0.4389 \\
\hline At most 1 & 5.0273 & 3.8415 & 0.0249 & 5.0273 & 3.8415 & 0.0249 \\
\hline
\end{tabular}

Source: Secondary Data Processed, $2018^{* *}=(\alpha) 0,05^{*}=(\alpha) 0,10$.

Based on the cointegration results, it can be concluded that the price of beef in kupang district does not follow the development of beef prices in Jakarta so that price information from Jakarta is not followed by price developments in kupang district so that there can be suspected attempts to increase the profit opportunity of sending beef to Jakarta by allowing prices of beef in Kupang is relatively low.

The results of the causality test, presented in Table 6, show that changes in beef price in Kupang city influence the beef price in Kupang district and Vice versa (two-way causality relationships). There is a two-way causality relationship between the beef price in Jakarta and Kupang District, where beef prices in Jakarta and Kupang district influence each other, but the price of meat in the city of Kupang does not affect the price of meat in Jakarta (oneway causality). This condition occurred allegedly because of asymmetric pricing information.

Table 6 - Granger Causality Test, Reciprocal Relationship between Market Levels

\begin{tabular}{llll}
\hline Null Hypothesis: & Obs & F-Statistic & Prob. \\
\hline KUPANG CITY does not Granger Cause KUPANG DISTRICT & 70 & 4.48767 & $0.0149^{* *}$ \\
KUPANG DISTRICT does not Granger Cause KUPANG CITY & & 2.43667 & $0.0954^{*}$ \\
\hline KUPANG DISTRICT does not Granger Cause JAKARTA & 70 & 2.47917 & $0.0917^{*}$ \\
JAKARTA does not Granger Cause KUPANG DISTRICT & & 4.86114 & $0.0108^{* *}$ \\
\hline KUPANG CITY does not Granger Cause JAKARTA & 70 & 1.85818 & 0.1641 \\
JAKARTA does not Granger Cause KUPANG CITY & & 3.07562 & $0.0529^{*}$ \\
\hline
\end{tabular}

Source: Secondary Data Processed, $2018^{* *}=(\alpha) 0,05^{*}=(\alpha) 0,10$.

The results of Weldesenbet's research (2013), found that price asymmetry leads to a lack of integrated markets. Whereas Malý's (2013) found that the increase in the price of beef in Czech between consumers and producers did not move proportionally. In other words, it did not have a direct relationship. So that, even though there is an increase in beef cattle production input prices in Kupang district it will not affect the price of beef, because beef prices are influenced by buyers in Jakarta. Svoboda \& Kopecka, (2017), in their studies, found that an increase in the price of production inputs did not change the price of the product, this could cause producers of agricultural products to lose, which resulted in a decrease in long-term production.

The estimation results of the VECM model show that the price of beef in Kupang and Kupang cities and in Jakarta is determined by the price of beef in Jakarta in different periods. This can be seen from the price of beef in Kupang district influenced by the price of beef in Jakarta at lag $(-2)$ and the price of beef in the city of Kupang influenced by the price of beef in Jakarta at lag (-2) and lag (-3). While the price of beef in Jakarta is influenced by the price of beef in Jakarta itself at lag (-3), presented in Table 7 . This condition is in line with what is shown in figure 1 that the movement of beef prices between in Jakarta, Kupang city and, 
Kupang regency has a trend which rises but the pattern of movement between the three markets is not always in the same direction.

Table 7-Results of the VECM Test between Beef Prices in Jakarta, Kupang City, and Kupang District

\begin{tabular}{|c|c|c|c|}
\hline Error Correction: & $\mathrm{D}(\mathrm{P}$ JAKARTA $)$ & $\mathrm{D}(\mathrm{P} \quad \mathrm{KUPANG}$ CITY $)$ & $\mathrm{D}\left(\mathrm{P} \_\right.$KUPANG DISTRICT $)$ \\
\hline CointEq1 (ECT) & $\begin{array}{l}0.8707 \\
(0.6467) \\
{[1.3463]}\end{array}$ & $\begin{array}{l}1.2289 \\
(0.5105) \\
{[2.4071]^{\star *}}\end{array}$ & $\begin{array}{l}-1.75020 \\
(0.8393) \\
{[-2.0854]^{\star *}}\end{array}$ \\
\hline $\mathrm{D}\left(\mathrm{P}_{-}\right.$KUPANG DISTRICT $\left.(-1)\right)$ & $\begin{array}{l}-0.5206 \\
(0.5564) \\
{[-0.9355]}\end{array}$ & $\begin{array}{l}-0.9299 \\
(0.4392) \\
{[-2.1172]^{\star *}}\end{array}$ & $\begin{array}{l}0.5039 \\
(0.7221) \\
{[0.6979]}\end{array}$ \\
\hline $\mathrm{D}\left(\mathrm{P}_{-}\right.$KUPANG DISTRICT (-2)) & $\begin{array}{l}-0.2468 \\
(0.4400) \\
{[-0.5608]}\end{array}$ & $\begin{array}{l}-0.6332 \\
(0.3473) \\
{[-1.8232]^{*}}\end{array}$ & $\begin{array}{l}0.2224 \\
(0.5710) \\
{[0.3895]}\end{array}$ \\
\hline D(P_KUPANG DISTRICT (-3)) & $\begin{array}{l}-0.1537 \\
(0.2934) \\
{[-0.5236]}\end{array}$ & $\begin{array}{l}-0.2638 \\
(0.2316) \\
{[-1.1390]}\end{array}$ & $\begin{array}{l}0.1837 \\
(0.3808) \\
{[0.4823]}\end{array}$ \\
\hline D(P_KUPANG DISTRICT (-4)) & $\begin{array}{l}0.1112 \\
(0.1558) \\
{[0.7139]}\end{array}$ & $\begin{array}{l}0.03802 \\
(0.1229) \\
{[0.3092]}\end{array}$ & $\begin{array}{l}0.0831 \\
(0.2021) \\
{[0.4113]}\end{array}$ \\
\hline $\mathrm{D}\left(\mathrm{P}_{-}\right.$KUPANG CITY $\left.(-1)\right)$ & $\begin{array}{l}0.7149 \\
(0.569) \\
{[1.256]}\end{array}$ & $\begin{array}{l}0.5383 \\
(0.4493) \\
{[1.1980]}\end{array}$ & $\begin{array}{l}-0.8419 \\
(0.7387) \\
{[-1.1397]}\end{array}$ \\
\hline $\mathrm{D}\left(\mathrm{P}_{-}\right.$KUPANG CITY $\left.(-2)\right)$ & $\begin{array}{l}0.4890 \\
(0.4255) \\
{[1.1491]}\end{array}$ & $\begin{array}{l}0.2715 \\
(0.3359) \\
{[0.8073]}\end{array}$ & $\begin{array}{l}-0.7186 \\
(0.5522) \\
{[-1.3013]}\end{array}$ \\
\hline $\mathrm{D}\left(\mathrm{P}_{-}\right.$KUPANG CITY $\left.(-3)\right)$ & $\begin{array}{l}0.1294 \\
(0.3150) \\
{[0.4109]}\end{array}$ & $\begin{array}{l}-0.0612 \\
(0.2486) \\
{[-0.2460]}\end{array}$ & $\begin{array}{l}-0.5245 \\
(0.4087) \\
{[-1.2831]}\end{array}$ \\
\hline $\mathrm{D}\left(\mathrm{P}_{-}\right.$KUPANG CITY $\left.(-4), 2\right)$ & $\begin{array}{l}0.0983 \\
(0.1817) \\
{[0.54071}\end{array}$ & $\begin{array}{l}-0.1543 \\
(0.1435) \\
{[-1.0756]}\end{array}$ & $\begin{array}{l}-0.2479 \\
(0.2358) \\
{[-1.0512]}\end{array}$ \\
\hline$D\left(P \_J A K A R T A(-1)\right)$ & $\begin{array}{l}-0.2482 \\
(0.1571) \\
{[-1.5806]}\end{array}$ & $\begin{array}{l}0.2150 \\
(0.1240) \\
{[1.73429]^{*}}\end{array}$ & $\begin{array}{l}-0.2263 \\
(0.2038) \\
{[-1.1102]}\end{array}$ \\
\hline $\mathrm{D}\left(\mathrm{P} \_J A K A R T A(-2)\right)$ & $\begin{array}{l}-0.5717 \\
(0.1626) \\
{[-3.51507]^{\star *}}\end{array}$ & $\begin{array}{l}0.2687 \\
(0.1284) \\
{[2.0928]^{\star *}}\end{array}$ & $\begin{array}{l}-0.1764 \\
(0.2110) \\
{[-0.8360]}\end{array}$ \\
\hline$D(P$ JAKARTA(-3)) & $\begin{array}{l}-0.03976 \\
(0.1550) \\
{[-0.2566]}\end{array}$ & $\begin{array}{l}-0.0924 \\
(0.1223) \\
{[-0.7553]}\end{array}$ & $\begin{array}{l}-0.3816 \\
(0.2011) \\
{[-1.8977]^{*}}\end{array}$ \\
\hline $\mathrm{D}\left(\mathrm{P} \_J A K A R T A(-4)\right)$ & $\begin{array}{l}-0.11529 \\
(0.1427)\end{array}$ & $\begin{array}{l}0.1356 \\
(0.1126)\end{array}$ & $\begin{array}{l}0.07942 \\
(0.1851)\end{array}$ \\
\hline C & $\begin{array}{l}{[-0.8082]} \\
-25.2005 \\
(238.3440) \\
{[-0.1057]}\end{array}$ & $\begin{array}{l}{[1.2039]} \\
45.7600 \\
(188.1390) \\
{[0.2432]}\end{array}$ & $\begin{array}{l}{[0.4290]} \\
-42.6041 \\
(309.2990) \\
{[-0.1377]}\end{array}$ \\
\hline
\end{tabular}

Source: Secondary data (processed), $2018^{* *} \alpha=0.05$ and $\alpha=0.10$.

The effect of beef prices in Jakarta toward the price of beef in Kupang district and, Kupang city has a different effect that can be determined from the negative and positive values of the lagged error correction values. The negative value of the lagged error correction value means that the prices in the two regions move away from each other. This showed that prices in Kupang District move against the prices in Jakarta. This happened because Kupang district is a production area; sale of cattle more because of cash needs compared to the reason for the increase in beef prices. In accordance with Zainuddin's opinion, (2015), that changes in beef prices do not directly affect meat demand, because of the nature of livestock in Indonesia does not respond to price changes. This can be expected to occur information asymmetry as one of the causes of beef price movements in Kupang district is not in line with Jakarta. Communication facilities, facilities for marketing, transportation, and market information services that do not support an efficient marketing system. The same case was explained by Kofi and Vijaya (2016) on rice price movements in 
Ghana that the fallow market imperfection caused information asymmetry which resulted in rice prices in Ghana not being integrated. According to Kofi and Vijaya (2016), information asymmetry will result in rice prices not being integrated and what is often disadvantaged is on the part of the producers, so the role of government is very important by conducting interventions so that producers get reasonable prices, for example through basic pricing (Kinnucan \& Forker, 1987).

Evidence of cases of government intervention in Poland, several times has succeeded in overcoming turmoil in beef prices and other agricultural commodities, (Borawski, et al., 2018). There are three types of benefits from the government intervention on food commodity price stabilization policies according to Dawe (2001), namely (1) protecting farmers as producers from falling prices, (2) protecting lower middle class consumers with low income (poor consumers), and (3) creating more stable macroeconomic conditions.

\section{CONCLUSION AND RECOMMENDATIONS}

Based on the discussion above, it can be concluded that cointegration occurs between the price of beef in Kupang district and Kupang city but the price of beef in Kupang district and Kupang city is not integrated with the price of beef in Jakarta. There is no short-term integration between the price of beef in Kupang District and in Kupang City. However, shortterm integration occurs between the price of beef in Kupang district, Kupang city and Jakarta with beef prices in Jakarta but each of them have a different balance direction. The direction of the balance movement is the opposite between the price of beef in Kupang regency and the prices in Jakarta, while the price of beef in the city of Kupang and in Jakarta occurs the opposite. Therefore, in order to improve the market condition in the Province of East Nusa Tenggara, it is necessary to improve accurate, fast and transparent market information systems and services to market participants, especially producers and government intervention is needed to help producers in determining the reasonable beef price.

\section{REFERENCES}

1. Anindita, R,. \& Baladina, N. 2017. Pemasaran Produk Pertanian. Penerbit Andi Offcet. Yogyakarta.

2. Asmarantaka, R.W. 2009. Pemasaran Produk-produk Pertanian. Bunga Rampai Agribisnis: Seri Pemasaran. Bogor IPB Press.

3. Baffes, J,. \& Gardner, B. 2003. The transmission of World Commodity Prices to Domestic Markets under Policy Reforms in Developing Countries. Policy Reform, Journal of Economic Policy Reform 6(3), 159-180.

4. Borawski, P., Beldycka-Borawska, A., \& Dunn, J. W. 2018. Price Volatility of Polish Agricultural Commodities in the View of the Common Agricultural Policy. Agricultural Economics/Zemedelska Ekonomika, 64(5).

5. Crucini, M. J., Shintani, M., \& Tsuruga, T. 2010. The law of one price without the border: the role of distance versus sticky prices. The Economic Journal, 120(544), 462-480.

6. Dawe, D. 2001. How far down the path to free trade? The importance of rice price stabilization in developing Asia. Food Policy, 26(2), 163-175.

7. Dinas Pertanian NTT. 2017. Data Pengiriman Sapi ke Luar NTT, tahun 2015-2017.

8. Enders, W. 1995. Applied Applied Econommetric Time Series., New York: Jonh Wiley\&Sons. Inc. Göktaş, Ö.2005 Teorik ve Uygulamalı Zaman Serileri Analizi, İstanbul: Beşir Kitabevi

9. Fakari, B., Farsi, M. M., \& Kojouri, M. 2013. Determining Fluctuations and Cycles of Corn Price in Iran. Agricultural Economics/ Zemedelska Ekonomika, 59(8).

10. Gujarati D. 200. Basics Econometrics, Fourth Edition. New York (US): The McGraw Hill Companies.

11. Kementerian Perdagangan. 2010. Rencana Strategis Kementerian Perdagangan Periode 2010-2014. Kementerian Perdagangan RI, Jakarta. 
12. Kementerian Pertanian. 2017. Statistik Peternakan dan Kesehatan Hewan 2017. Penerbit Direktorta Jenderal Peternakan dan Kesehatan Hewan Kementan RI, Jakarta.

13. Kofi, J. B,. \& Vijaya, R. K. 2016. Market Integration and Price Transmission Between Selected Imported Rice and Local Rice Markets in Ghana: Application of Non-Linear CoIntegration Approach. Journal Agriculture and Forestry Science. Vol. 4 (2), pp. 1-7.

14. Makridakis, S,. Wheelwright, S.C,. \& McGee, V.E. 1999. Metode dan Aplikasi Peramalan. Jilid I. Edisi 2. Jakarta: Erlangga.

15. Malý, M. 2013. Partial Equilibrium Model-Beef. Agricultural Economics/ Zemedelska Ekonomika, 59(6).

16. Monke E,. \& Petzel T. 1984. Market Integration: an Application to International Trade in Cotton. Am J Agric Econ. 66(4):481-487.

17. Pusdatin Kementerian Pertanian RI. 2017. Outlook Daging Sapi, Komoditas Pertanian Subsektor Peternakan. Penerbit Pusata data dan Informasi Pertanian, Sekretaris Jenderal Kementerian Pertanian RI, Jakarta.

18. Sharp, P. R., \& Uebele, M. 2013. Rural Infrastructure and Agricultural Market Integration in the United States: a Long Run Perspective.

19. Sulistiana, I. 2017. Model Vector Auto Regression (VAR) and Vector Error Correction Model (VECM) Approach for Inflation Relations Analysis, Gross Regional Domestic Product (GDP), World Tin Price, Bi Rate and Rupiah Exchange Rate. Integrated Journal of Business and Economics, 1(2), 17-32.

20. Svoboda, R., \& Kopecka, L. 2017. The Sweezy Model of Price Competition Among Private Labels of Chain Stores. Agricultural Economics (Zemědělská Ekonomika), 63(7), 299-307.

21. Weldesenbet, T. 2013. Asymmetric Price Transmission in the Slovak Liquid Milk Market. Agricultural Economics/Zemedelska Ekonomika, 59(11).

22. Widaryono, A. 2013. Ekonometrika Pengantar dan Aplikasinya, Disertai Panduan Eviews. UPP STIM YKPN. Yogyakarta.

23. Zainuddin, A. 2015. Integrasi Pasar dan Respon Penawaran Daging Sapi di Indonesia (Doctoral Dissertation, Bogor Agricultural University). 